\title{
AN EMPIRICAL STUDY ABOUT THE EFFECTS OF 'BUSINESS TAX REFORMED TO VAT' ON FIRMS’ BARGAINING POWER - BASED ON DID MODEL
}

\author{
Yanling Wang \\ Shanghai University, P.R.China \\ Jiaxi Wang \\ Shanghai University of Finance and Economics, P.R.China
}

\begin{abstract}
This paper empirically examines whether the Business Tax reformed to VAT policy has an impact on the bargaining power of reformed industry firms based on DID Model by using the A-share companies listed in both Shanghai Stock Exchange and Shenzhen Stock Exchange from 2010-2015. The bargaining power of firms is divided into two parts: the bargaining power of firms when negotiating with their suppliers and the bargaining power of firms when negotiating with their distributors. The research findings support the idea that the policy does have an impact on the bargaining power of reformed industry firms, the specific impact of the policy is to reduce firms' bargaining power when negotiating with suppliers, and improve their bargaining power when negotiating with dealers.
\end{abstract}

Keywords: Business Tax reformed to VAT, bargaining power, DID model

JEL code: M40

\section{Introduction}

'Business Tax reformed to VAT' policy was firstly put into practice in ' $1+6$ ' industries in Shanghai on January 1, 2012. After that, the reformed area and industries experience a gradual expansion in China from May 1, 2016. The main purpose of the government to implement the policy is to reduce the tax burden of firms, promote economic development and mobilize the enthusiasm of all parties. However, the actual impacts of the policy in implementation process are unsure and very complex. Since the implementation of the policy, multifaceted researches have been done to study the actual impacts of it. 
Current researches mainly focus on the aspects of firm performance, turnover tax burden, division of labor, investment in innovative intangible assets, etc. Few studies have examined the influences of the policy on bargaining power of the firm. Previous studies in this area mainly are qualitative theoretical analysis and indirect research. $\mathrm{Hu}$ (2013) uses a qualitative theoretical framework to study this problem, and points out that the upstream firms' bargaining power could be improved because firms are allowed to deduct input tax deduction after the implementation of the policy. Tong (2015) studies the relationship among the policy, the turnover tax and the bargaining power, and quantitatively analyzes the policy impact on turnover tax burden basing on different bargaining power. Although bargaining power is included in these researches, it is not the main point. This study intends to study the 'Business Tax reformed to VAT' policy impact on firms from the angel of bargaining power. Bargaining power is a very important factor influencing operating condition of firms. Costs of raw materials are strongly influenced by firms' bargaining power when negotiating with the suppliers. Moreover, firms' bargaining power when negotiating with the dealers can affect product price, sales and ultimately the corporate profits. In addition, the study can be also helpful for the government.

Based on the data of Chinese listed companies from 2010 to 2015, this study uses DID model to study the policy impact on bargaining power and the possible impact path.

The remainder of the paper is organized as follows. Section 2 develops our theoretical framework and presents the hypotheses that we test. Section 3 outlines data collection and research design. Descriptive statistics and multivariate analysis are presented in section 4 . Section 5 contains the summary and conclusion of the study.

\section{Theoretical Analysis and Research Hypothesis}

Hu (2013) suggest that the 'Business Tax reformed to VAT' policy might have a certain impact on the bargaining power of firms. After the reform, firms are allowed to carry out input tax deduction. Therefore, the upstream manufacturers become the invoice issuer and the downstream manufacturers will ask invoice from them in order to deduct input tax. In the bargaining game, this relationship will make the upstream manufacturers occupy a favorable position and enhance their bargaining power to a certain extent. Relatively, the downstream manufacturers' bargaining power will be weakened.

As shown in Figure 1, the bargaining power of firms can be divided into two parts: dealer bargaining power and supplier bargaining power. For a specific firm involved in the reform, relative to its suppliers, the role of the firm is the dealer and the bargaining power of it when negotiating with suppliers is called the reformed firm's 
dealer bargaining power. Relative to the dealer, the role of the firm is the supplier. When negotiating with dealers, the bargaining power of the reformed firm is called supplier bargaining power. In the bargaining game with suppliers, the firm is in the downstream and the party to ask for invoice. The power of the firm to bargain with its suppliers is weakened, that is, the firm's dealer bargaining power is weakened. In the bargaining game with dealers, the firm is in the upstream and the invoice issuer. In a favorable position, the power of the firm to bargain with its dealers is improved, that is, the firm's supplier bargaining power is improved.

Based on the above theoretical analysis, as a supplier, after the implementation of the policy, the firm involved in the reform will have stronger power to bargain with its dealers, that is, its supplier bargaining power will be improved. As a dealer, after the implementation of the policy, the power of the firm to bargain with its suppliers will be weakened, that is, its dealer bargaining power will be weakened. Therefore, we state our hypotheses as follows:

H1: Other things unchanged, compared to the control group of non-reformed firms, 'Business Tax reformed to VAT' policy will weaken the dealer bargaining power of experimental group of reformed firms, that is, the experimental group's power to bargain with their suppliers will be weakened.

H2: Other things unchanged, compared to the control group of non-reformed firms, 'Business Tax reformed to VAT' policy will improve the supplier bargaining power of experimental group of reformed firms, that is, the experimental group's power to bargain with their dealers will be improved.

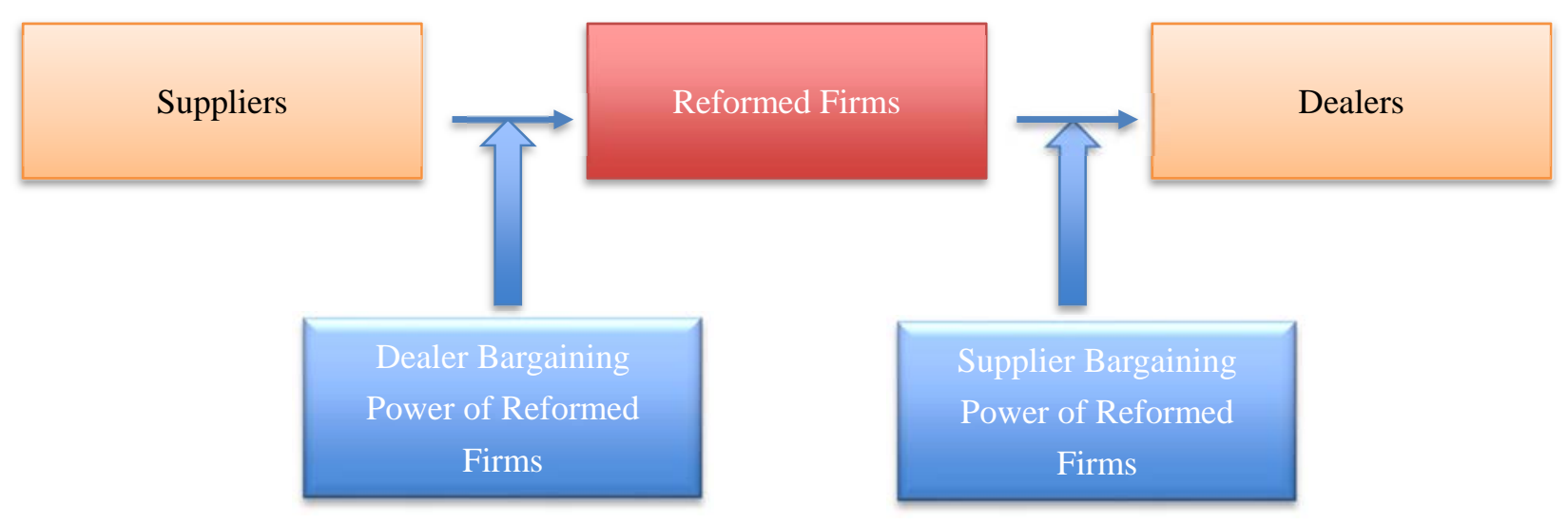

Figure 1. Bargaining Power of the Firm

\section{Sample Selection and Research Design}

\subsection{Sample Selection and Data Source}

Our sample consists of all Chinese A-share listed companies and data from 2010 to 
2015 are collected in the study. The Sample selection procedure is outlined as follows: we first exclude the companies of which data is missing in any year and the null values. Then we exclude $S T$ and $S T^{*}$ listed companies. Lastly, we trim extreme observations at the $1^{\text {st }}$ and $99^{\text {th }}$ percentiles based on bargaining power.

We then divide our sample into two groups, the supplier data group and the dealer data group. There are 275 listed companies, a total of 1650 observations in the supplier data group. 505 listed companies are included in the dealer data group, a total of 3030 observations. The listed companies in each group are further divided into experimental group and control group. The listed companies in the experimental group pay business tax before the reform while VAT after the reform. The listed companies in the control group pay VAT all the time. All the data are collected from CSMAR and we use Stata to analyze the data.

\subsection{Variable Selection and DID Model}

As mentioned earlier, the bargaining power of firms can be divided into dealer bargaining power and supplier bargaining power. When the firm bargain with its dealers, it acts as a supplier. Therefore, the firm's power to bargain with its dealers is reflected in its supplier bargaining power. On the contrary, when bargaining with suppliers, the the firm becomes the dealer. Therefore, the firm's power to bargain with its suppliers is reflected in its dealer bargaining power. To test our hypotheses, we need to measure the bargaining power of suppliers and distributors. We estimate the concentration of suppliers and distributors as the dealer bargaining power and supplier bargaining power. Previous studies show that the most commonly used variables to measure the concentration of suppliers and distributors are the top five distributors' and suppliers' share of business. The larger the share of the top five suppliers is, the higher the concentration of suppliers, the higher the degree of dependence of the firm on the suppliers and the weaker the power of the firm to bargain with its suppliers, that is, the weaker the dealer bargaining power of the firms is. The lower the share of the top five dealers is, the lower the concentration of dealers, the lower the degree of dependence of the firm on the dealer, the stronger the power of the firm to bargain with its dealers (Tang, 2009), that means, the supplier bargaining power of firms is stronger. In short, share change of the top five dealers and suppliers of listed companies will be used to measure the change in supplier and dealer bargaining power.

When the power of the firm to bargain with suppliers is weakened, the degree of their dependence on suppliers will be improved. Reflected in the selected variables, the share of top five suppliers will increase. The degree of dependence on dealers will decrease if the power of the firm to bargain with dealers is enhanced. Reflected in the selected variables, the share of top five dealers will decrease. Usually, the DID model is used to evaluate the policy impact (Ye, 2013). This study chooses the DID model 
and sets the reformed listed companies as the experimental group, and the non-reform listed companies as the control group. The model is constructed as follows:

$$
\begin{gathered}
\text { Power }_{i l t}=\alpha \text { Policy }_{l t}+\beta \text { Treat }_{i}+\gamma \text { Policy }_{l t} * \text { Treat }_{i}+\theta_{t}+\delta_{i}+\text { Timetrend }_{i} \\
+\varepsilon_{i l t}
\end{gathered}
$$

Power $_{\text {ilt }}$ means firm i's top five suppliers or dealers share in location $l$ for year $t$. Policy $_{l t}$ is an indicator variable that is coded 1 if province $l$ is included in the reformed area for year t, and 0 otherwise. Treat $_{i}$ equals 1 if firm $i$ is a reformed firm, and otherwise 0 . The difference-in-differences effect is captured by Policy ${ }_{i t} *$ Treat $_{i}$. We use $\theta_{t}$ to control the fixed effect of year and $\delta_{i}$ to control for the firm's fixed effect. The provinces are allowed to have different linear trends over time and the changes are showed by the variable Timetrend ${ }_{i}$. The meaning of each variable is summarized in Table 1 , and Table 2 shows the changes of years and regions over time.

Table 1. Variable Definitions

\begin{tabular}{|c|l|}
\hline Variables & \multicolumn{1}{c|}{ Meanings } \\
\hline Power $_{\text {ilt }}$ & The share of top five suppliers or dealers of firm i in province l in year $\mathrm{t}$ \\
\hline Policy $_{l t}$ & Whether province l is included in the reformed area in year t or not \\
\hline Treat $_{i}$ & Whether firm $\mathrm{i}$ is a reformed firm or not \\
\hline$\theta_{t}$ & The fixed effect of year \\
\hline$\delta_{i}$ & The firm's fixed effect \\
\hline Timetrend $_{i}$ & The cross of year and province dummy variables \\
\hline
\end{tabular}

Table 2. The Change in Reformed Areas and Industries

\begin{tabular}{|c|c|c|}
\hline The Start Time & Reformed Industry & Reformed Areas \\
\hline January 1, 2012 & ' $1+6$ ' Industry & Shanghai \\
\hline September 1, 2012 $1+6$ ' Industry & Beijing \\
\hline October 1, 2012 & ' $1+6$ ' Industry & Anhui, Jiangsu \\
\hline November 1, 2012 $1+6$ ' Industry & Fujian, Guangdong \\
\hline December 1, 2012 $11+6$ ' Industry & Hubei, Zhejiang, Tianjin \\
\hline August 1, 2013 & '1+6’ Industry & The Whole Country \\
\hline August 1, 2013 & $\begin{array}{c}\text { Radio and Television Service } \\
\text { Industry }\end{array}$ & The Whole Country \\
\hline January 1, 2014 & $\begin{array}{c}\text { Rail Transport Industry, Postal } \\
\text { Industry }\end{array}$ & The Whole Country \\
\hline June 1, 2014 & Telecommunications Industry & The Whole Country \\
\hline
\end{tabular}

In the above model, we focus on the coefficient of Policy $_{i t} *$ Treat $_{i}$. Only when Treat and Policyit both equal 1, the variable Policy it $^{*}$ Treat $_{i}$ has an effect on the Power. When Policy $_{i t} *$ Treat $_{i}$ equals 1 , it means that the sample is a reformed firm, in a reformed area and in the reformed year. According to hypothesis 1, compared to the non-reformed listed companies, the coefficient of Policy it Treat $_{i}$ is expected to be significantly positive if the power of reformed firms to bargain with suppliers is indeed weakened. According to hypothesis 2, compared to the non-reformed listed 
companies, the coefficient of Policy $_{i t} *$ Treat $_{i}$ is expected to be significantly negative if the power of reformed firms to bargain with dealers is improved.

The control variables are from extant research. According to Tong (2015) and Tang (2009), we include firm scale (natural log of total assets), concentration ratio (Hirschman-Herfindahl Index), the nature of firm's ownership, accounts receivable ratio and accounts payable ratio as our control variables.

\section{Empirical Results and Analysis}

\subsection{Descriptive statistics}

Descriptive statistics for the sample are in table 3. Panel A shows the descriptive statistics for the supplier data group while panel B shows the descriptive statistics for the dealer data group. The number of observations for the dearlers group is greater than the number of observations for the suppliers data group (3,030 versus 1,650). The mean (median) value of Power were 35.717 (31.90) for the supplier data group and 30.845 (45.515) for the dealers data group. The mean value of Treat is higher for the supplier data group than for the dealers data group. There is no big difference of the mean value of Policy between these two groups.

Table 3. Descriptive Statistics of Main Variables

\begin{tabular}{|c|c|c|c|c|c|}
\hline \multicolumn{7}{|c|}{ Panel A: The Suppliers Data Group (n=1,650) } \\
\hline \multirow{2}{*}{ Variable } & Mean & Median & $\begin{array}{c}\text { Standard. } \\
\text { Deviation. }\end{array}$ & Min & Max \\
\hline Power & 35.717 & 31.90 & 19.139 & 0.69 & 100 \\
\hline Treat & 0.425 & 0 & 0.495 & 0 & 1 \\
\hline Policy & 0.513 & 1 & 0.499 & 0 & 1 \\
\hline \multicolumn{2}{|c|}{ Panel B: The Dealers Data Group (n=3,030) } \\
\hline Variable & Mean & Median & Standard. & Min & Max \\
\hline Power & 30.845 & 45.515 & 20.873 & 1.06 & 100 \\
\hline Treat & 0.143 & 0 & 0.35 & 0 & 1 \\
\hline Policy & 0.56 & 1 & 0.489 & 0 & 1 \\
\hline
\end{tabular}

\subsection{Empirical Test Results}

\subsubsection{Analysis on the Influence of 'Business Tax Reformed to VAT' on Firms' Dealer Bargaining Power}


Table 4. Analysis of the Policy Effects on Dealer Bargaining Power of reformed firm

\begin{tabular}{|c|c|c|c|c|c|}
\hline & $(1)$ & $(2)$ & (3) & (4) & (5) \\
\hline & OLS & OLS & OLS & FE & $\mathrm{FE}$ \\
\hline & Power_jxs & Power_jxs & Power_jxs & Power_jxs & Power_jxs \\
\hline Treat & $\begin{array}{c}-7.142 * * * \\
(0.001)\end{array}$ & $\begin{array}{c}-6.914 * * * \\
(0.001)\end{array}$ & $\begin{array}{c}-6.941 * * * \\
(0.002)\end{array}$ & & \\
\hline Policy & $\begin{array}{c}-2.023^{* *} \\
(0.030)\end{array}$ & $\begin{array}{c}-7.378 * * * \\
(0.004)\end{array}$ & $\begin{array}{c}-5.947 * * * \\
(0.001)\end{array}$ & $\begin{array}{c}-5.394 * * * \\
(0.001)\end{array}$ & $\begin{array}{c}-4.663 * * * \\
(0.001)\end{array}$ \\
\hline Treat*Policy & $\begin{array}{c}13.171^{* * *} \\
(0.000)\end{array}$ & $\begin{array}{c}13.048 * * * \\
(0.000)\end{array}$ & $\begin{array}{c}13.327 * * * \\
(0.000)\end{array}$ & $\begin{array}{c}12.210 * * * \\
(0.000)\end{array}$ & $\begin{array}{c}11.593^{* * *} \\
(0.000)\end{array}$ \\
\hline $\begin{array}{c}\text { Fixed Effect of } \\
\text { Year } \\
\end{array}$ & & Yes & Yes & Yes & Yes \\
\hline Timetrend & & & Yes & & Yes \\
\hline $\begin{array}{l}\text { Firm' Fixed } \\
\text { Effects }\end{array}$ & & & & Yes & Yes \\
\hline Constant Term & $\begin{array}{c}36.484 * * * \\
(0.000)\end{array}$ & $\begin{array}{c}35.677 * * * \\
(0.000)\end{array}$ & $\begin{array}{c}29.096 * * * \\
(0.000)\end{array}$ & $\begin{array}{c}32.736 * * * \\
(0.000)\end{array}$ & $\begin{array}{c}-1.1 \mathrm{e}+03^{* * *} \\
(0.000)\end{array}$ \\
\hline \multicolumn{6}{|c|}{ Control variables included but not reported for the sake of brevity } \\
\hline$N$ & 1650 & 1650 & 1650 & 1650 & 1650 \\
\hline Within $\mathrm{R}^{2}$ & 0.036 & 0.041 & 0.094 & 0.117 & 0.161 \\
\hline
\end{tabular}

Note: The values in parentheses are P values. All results are calculated using the clustering standard error at the provincial level. ***,**and* represent $1 \% 、 5 \%$ 和 $10 \%$ significance levels. Power.gys means supplier bargaining power of firms. Power,jxs means dealer bargaining power of firms.

Results of the policy effects on dealers bargaining power of the reformed firm are presented in Table 4. For the sake of comparisons, regressions are reported with and without fix effect of firm and year. Policy it $^{*}$ Treat $_{i}$ are significantly positive in the normal OLS and the fixed effect regressions, indicating that the policy does improve the top five suppliers' share of the reformed firm. This suggests that the 'Business Tax Reformed to VAT' policy does enhance the top five suppliers' concentration, improve the reformed firms' degree of dependence on its suppliers, reduce the dealers bargaining power of the reformed firm. This supports Hypothesis 1.

\subsubsection{Analysis on the Influence of 'Business Tax Reformed to VAT' on Firms' Supplier Bargaining Power}


Table 5. Analysis of the Policy Effects on Supplier Bargaining Power of reformed firm

\begin{tabular}{|c|c|c|c|c|c|}
\hline & (1) & (2) & (3) & (4) & (5) \\
\hline & OLS & OLS & OLS & FE & FE \\
\hline & Power_gys & Power_gys & Power_gys & Power_gys & Power_gys \\
\hline Treat & $\begin{array}{l}-12.438 * * * \\
(0.000)\end{array}$ & $\begin{array}{l}-12.346^{* * *} \\
(0.000)\end{array}$ & $\begin{array}{l}-11.439 * * * \\
(0.000)\end{array}$ & & \\
\hline Policy & $\begin{array}{l}1.602 * \\
(0.067) \\
\end{array}$ & $\begin{array}{l}1.146 \\
(0.642)\end{array}$ & $\begin{array}{l}2.473^{* *} \\
(0.017) \\
\end{array}$ & $\begin{array}{l}2.274^{* *} \\
(0.022)\end{array}$ & $\begin{array}{l}1.724^{*} \\
(0.065) \\
\end{array}$ \\
\hline Treat*Policy & $\begin{array}{l}-5.284 * * * \\
(0.002)\end{array}$ & $\begin{array}{l}-5.409 * * * \\
(0.002)\end{array}$ & $\begin{array}{l}-5.416^{* * *} \\
(0.002)\end{array}$ & $\begin{array}{l}-4.706 * * * \\
(0.001)\end{array}$ & $\begin{array}{l}-3.472 * * * \\
(0.007)\end{array}$ \\
\hline $\begin{array}{l}\text { Fixed Effect of } \\
\text { Year }\end{array}$ & & Yes & Yes & Yes & Yes \\
\hline Timetrend & & & Yes & & Yes \\
\hline $\begin{array}{l}\text { Firm's } \quad \text { Fixed } \\
\text { Effect }\end{array}$ & & & & Yes & Yes \\
\hline Constant Term & $\begin{array}{l}43.892 * * * \\
(0.000)\end{array}$ & $\begin{array}{l}43.141^{* * *} \\
(0.000)\end{array}$ & $\begin{array}{l}33.929 * * * \\
(0.000)\end{array}$ & $\begin{array}{l}39.719 * * * \\
(0.000)\end{array}$ & $\begin{array}{l}619.126^{* * *} \\
(0.000)\end{array}$ \\
\hline Control variables i & luded but I & eported for & e of brevity & & \\
\hline $\mathrm{N}$ & 3030 & 3030 & 3030 & 3030 & 3030 \\
\hline Within R2 & 0.093 & 0.094 & 0.144 & 0.014 & 0.057 \\
\hline
\end{tabular}

Note: The values in parentheses are P values. All results are calculated using the clustering standard error at the provincial level. $* * * * *$ and $*$ represent $1 \% 、 5 \%$ 和 $10 \%$ significance levels. Power.gys means supplier bargaining power of firms. Power,jxs means dealer bargaining power of firms.

Results of the policy effects on suppliers bargaining power of the reformed firm are presented in Table 5. For the sake of comparisons, regressions are reported with and without fix effect of firm and year. Policy ${ }_{i t} *$ Treat $_{i}$ are significantly negative in the normal OLS and the fixed effect regressions, indicating that the policy does reduce the top five dealers' share of the reformed firm. This suggests that the 'Business Tax Reformed to VAT' policy does reduce the top five dealers' concentration, weaken the reformed firms' degree of dependence on its dealers, improve the suppliers bargaining power of the reformed firm. This supports Hypothesis 2.

\subsubsection{Sub-industry Test Results}

Then we examine the impact of the policy on the bargaining power of different 
industries and firms. Until 2015, there are three major categories of industries that have been reformed: transportation, telecommunications and modern services industries, respectively. Among the experimental groups that have been reformed, modern services include leasing and business services, cultural, sports and entertainment, health and social work, radio and television services, and scientific research and technical services. We use the sub-industry test to study whether the policy has significant impacts on the bargaining power of firms in reformed industry, whether there is any difference of the impact on different industries. Results are shown in Table 6:

Table 6. Empirical Results of Sub-Industry Test

\begin{tabular}{|c|c|c|c|c|c|c|}
\hline & (1) & (2) & (3) & (4) & (5) & (6) \\
\hline & \multicolumn{2}{|c|}{$\begin{array}{l}\text { Telecommunications } \\
\text { Industry }\end{array}$} & \multicolumn{2}{|c|}{ Transportation Industry } & \multicolumn{2}{|l|}{$\begin{array}{l}\text { Modern } \\
\text { Industry }\end{array}$} \\
\hline & $\begin{array}{l}\text { Power_jx } \\
\text { S }\end{array}$ & Power_gys & Power_jxs & Power_gys & Power_jxs & Power_gys \\
\hline Policy & $\begin{array}{l}-1.679 \\
(0.268) \\
\end{array}$ & $\begin{array}{l}1.101 \\
(0.243) \\
\end{array}$ & $\begin{array}{l}-2.306 \\
(0.146) \\
\end{array}$ & $\begin{array}{l}0.594 \\
(0.490) \\
\end{array}$ & $\begin{array}{l}-3.747^{* *} \\
(0.011) \\
\end{array}$ & $\begin{array}{l}1.309 \\
(0.165) \\
\end{array}$ \\
\hline Treat*Policy & $\begin{array}{l}11.117^{* *} \\
* \\
(0.000)\end{array}$ & $\begin{array}{l}-2.772 * \\
(0.064) \\
\end{array}$ & $\begin{array}{l}6.544 * * * \\
(0.006)\end{array}$ & $\begin{array}{l}-3.875 * \\
(0.096) \\
\end{array}$ & $\begin{array}{l}13.187^{* * *} \\
(0.000) \\
\end{array}$ & $\begin{array}{l}-4.164 * \\
(0.062) \\
\end{array}$ \\
\hline $\begin{array}{l}\text { Fixed Effect of } \\
\text { Year }\end{array}$ & Yes & Yes & Yes & Yes & Yes & Yes \\
\hline Tinetrend & Yes & Yes & Yes & Yes & Yes & Yes \\
\hline $\begin{array}{l}\text { Firm's Fixed } \\
\text { Effect }\end{array}$ & Yes & Yes & Yes & Yes & Yes & Yes \\
\hline Constant Term & $\begin{array}{l}-914.170 \\
* * * \\
(0.000)\end{array}$ & $\begin{array}{l}349.396 * * \\
* \\
(0.000)\end{array}$ & $\begin{array}{l}731.475^{* *} \\
* \\
(0.000)\end{array}$ & $\begin{array}{l}1376.133^{*} \\
* * \\
(0.000)\end{array}$ & $\begin{array}{l}-86.880 \\
(0.673)\end{array}$ & $\begin{array}{l}1467.810^{*} \\
* * \\
(0.000)\end{array}$ \\
\hline \multicolumn{7}{|c|}{ Control variables included but not reported for the sake of brevity } \\
\hline $\mathrm{N}$ & 1302 & 2610 & 1056 & 2346 & 1188 & 2454 \\
\hline Within R2 & 0.145 & 0.060 & 0.093 & 0.071 & 0.141 & 0.060 \\
\hline
\end{tabular}

Note: The values in parentheses are $\mathrm{P}$ values. All results are calculated using the clustering standard error at the provincial level. ***,**and* represent $1 \%$ 、5\% 和 $10 \%$ significance levels. Power.gys means supplier bargaining power of firms. Power,jxs means dealer bargaining power of firms. 
As can be seen, Policy $_{i t} *$ Treat $_{i}$ are significantly positive in all regressions of the suppliers data group and significantly negative in all regressions of the dealers data group. The results are qualitatively similar.

\subsubsection{Sub-regional Test Results}

In addition, we also examine the impact of the policy on the bargaining power of firms from different region. The purpose of the sub-regional research is to study whether the policy has significant impacts on bargaining power of firms in all reformed areas, whether there is any difference in the specific impact on firms in different reformed areas. The provinces are divided into three regions: The Central, the West and the East region according to the standard of national bureau of statistics of Chinese. Specifically, Shanxi, Neimenggu, Jilin, Heilongjiang, Anhui, Jiangxi, Henan, Hubei, and Hunan are included in the Central region. The West includes Sichuan, Chongqing, Guizhou, Yunnan, Xizang, Shanxi, Gansu, Ningxia, Qinghai and Xinjiang. The East includes Beijing, Tianjin, Hebei, Liaoning, Shanghai, Jiangsu, Zhejiang, Fujian, Guangdong, Guangxi and Hainan. Results are shown in Table 7:

Table 7. Empirical Results of Sub-Regional Test

\begin{tabular}{|c|c|c|c|c|c|c|}
\hline & (1) & (2) & (3) & (4) & (5) & (6) \\
\hline & \multicolumn{2}{|c|}{ The East Region } & \multicolumn{2}{|c|}{ The Central Region } & \multicolumn{2}{|c|}{ The West Region } \\
\hline & Power_jxs & Power_gys & Power_jxs & Power_gys & Power_jxs & Power_gys \\
\hline Policy & $\begin{array}{l}-6.063^{* * *} \\
(0.010)\end{array}$ & $\begin{array}{l}1.294 * \\
(0.078)\end{array}$ & $\begin{array}{l}-2.918 \\
(0.140)\end{array}$ & $\begin{array}{l}-1.956 \\
(0.335)\end{array}$ & $\begin{array}{l}-0.665 \\
(0.856)\end{array}$ & $\begin{array}{l}13.942 * * * \\
(0.000)\end{array}$ \\
\hline Treat*Policy & $\begin{array}{l}12.309 * * * \\
(0.000)\end{array}$ & $\begin{array}{l}-3.125^{* *} \\
(0.041)\end{array}$ & $\begin{array}{l}9.860 * * \\
(0.012) \\
\end{array}$ & $\begin{array}{l}-6.795 * * \\
(0.040)\end{array}$ & $\begin{array}{l}10.856 \\
(0.104) \\
\end{array}$ & $\begin{array}{l}-2.149 \\
(0.704) \\
\end{array}$ \\
\hline $\begin{array}{l}\text { Fixed Effect } \\
\text { of Year }\end{array}$ & Yes & Yes & Yes & Yes & Yes & Yes \\
\hline Timetrend & Yes & Yes & Yes & Yes & Yes & Yes \\
\hline $\begin{array}{l}\text { Firm's Fixed } \\
\text { Effect }\end{array}$ & Yes & Yes & Yes & Yes & Yes & Yes \\
\hline Constant Term & $\begin{array}{l}-3.1 \mathrm{e}+03 * * \\
* \\
(0.003)\end{array}$ & $\begin{array}{r}537.043 \\
(0.185) \\
\end{array}$ & $\begin{array}{l}878.387^{* * *} \\
(0.000) \\
\end{array}$ & $\begin{array}{l}-200.388 \\
(0.282) \\
\end{array}$ & $\begin{array}{l}1193.250 \\
(0.413) \\
\end{array}$ & $\begin{array}{l}4269.887^{* * *} \\
(0.001)\end{array}$ \\
\hline \multicolumn{7}{|c|}{ Control variables included but not reported for the sake of brevity } \\
\hline $\mathrm{N}$ & 1236 & 2154 & 246 & 474 & 168 & 402 \\
\hline 组内 $R 2$ & 0.180 & 0.040 & 0.105 & 0.105 & 0.194 & 0.093 \\
\hline
\end{tabular}


Note: The values in parentheses are P values. All results are calculated using the clustering standard error at the provincial level. ***,**and* represent $1 \%$ 、5\%和 $10 \%$ significance levels. Power.gys means supplier bargaining power of firms. Power,jxs means dealer bargaining power of firms.

The results are shown in table 7. For the sample from the East region and Central region, Policy $_{i t} *$ Treat $_{i}$ is significantly positive in the suppliers data group and significantly negative in the dealers data group, indicating that 'Business Tax Reformed to VAT' improves the supplier bargaining power of reformed firms in central and eastern regions and weakens the dealers bargaining power of them. However, for the sample from the West region, although Policy $_{i t} *$ Treat $_{i}$ is positive in suppliers data group and negative in dealers data group, neither of them is significant. This suggests that the bargaining power of the reformed firms in the western region has not been significantly affected by the 'Business Tax Reformed to VAT' policy. There are several reasons for this: First, it is relatively late for the west to be included in the reformed scope and the policy effect has not been fully reflected in a short period of time. Second, the reformed firms in the western region mainly belong to telecommunications industry. It is also very late for this industry to be included in the reformed industries. Last but not least, the economy of the western region is relatively backward compared to the central and eastern regions, and the relevant policy may be more likely to be hampered in the process of implementation.

\section{Conclusions and Recommendations}

Based on the data of Chinese A-share listed companies from 2010 to 2015, this study uses the difference in differences (DID) model to examine the impact of 'Business Tax Reformed to VAT' policy on firms' bargaining power. We find that the policy does have a significant impact on the bargaining power of the firms in the experimental group. Especially, the policy weakens firms' power to bargain with suppliers, that is, the dealers bargaining power of the reformed firm is weakened. In addition, the policy improves the reformed firms' power to bargain with dealers, namely, the reformed firms' supplier bargaining power is improved. The sub-industry regressions show the similar result with the full sample. The sub-regional regressions show that the policy has significant impacts on reformed firms in the central and eastern regions while the western region has not been significantly influenced. We believe our findings are potentially informative to regulators, suppliers and dealers.

When the dealer bargaining power of the firm is weakened, the costs of its raw material procurement will be improved. If the costs of other production links remain changed, the total production costs of the firm will increase and the performance of the firm will be negatively affected. However, when the supplier bargaining power of the firm is improved, it can raise product price to boost sales revenue. Firms should take positive responses to balance these two effects. On one hand, they will take advantage of the benefits brought by the policy. On the other hand, it is also necessary for them to try to minimize the negative impacts of the policy. 
The implementation of 'Business Tax Reformed to VAT' policy does bring benefits to some firms but can also have negative impacts on others. How to maximize total welfare of the whole society is a challenge for the government. In this study, 'Business Tax Reformed to VAT' policy affects reformed firms' bargaining power through input tax deduction. The upstream firms are positively affected by the policy while the downstream ones are negatively influenced. This policy may lead to the redistribution of social resources and rights and change the market's competitive environment. We recommend that the government should make great efforts to establish a sound value-added tax system corresponding to the laws and regulations.

\section{References}

Cai, X. (2012), 'Business Tax Reformed to VAT' reform steadily progress to achieve the stage effect', China Tax News, pp.11-28.

Cao, H. (2010), Government regulation under different bargaining power of the theme of the game analysis. Shanghai Normal University, Shanghai.

Chi, R.Y. \& Zhu, F. (2012), “Analysis of influencing factors of firm bargaining power: Zhejiang product empirical study”, Journal of Zhejiang University of Technology, no.1, pp. 1-5.

Duan, H.F. (2012), Research on 'Business Tax Reformed to VAT' in China's transportation industry. Zhejiang Institute of Finance and Economics, Hangzhou.

Tang, Y.J. (2009), “Supplier, dealer bargaining power and company performance”, China Industrial Economy, no.10, pp. 67-76.

Gong, H.F. (2016), "Financial industry, construction industry and 'Business Tax Reformed to VAT’ problem research”, Gansu Finance, no.1, pp.42-43.

Hu, Y.J. (2014), “Comprehensive deepening 'Business Tax Reformed to VAT' needs to promote the three breakthrough” Registered Tax Accountants, no.8, pp. 67-68.

Hu, Y.J. (2013), “Shanghai service industry 'Business Tax Reformed to VAT' reform effect analysis”. Science Development, no.1, pp. 55-64.

Huang, J.Z. (2014), “Advantages and disadvantages of 'Business Tax Reformed to VAT’ on modern service industry”, Modern Economic Information, no.3, pp. 230-238.

Li, D. (2015), “Business Tax Reformed to VAT' policy effect on tax burden of transportation industry” Journal of Shanghai Institute of Shipping and Transportation Science, no.6, pp. 71-74. 
Lin, Y. L. (2015), “Exploring the French 'Business Tax Reformed to VAT' impact on China’s tax reform”, Modern Business, no.6, pp. 80-81.

Liu, R. Z., et al. (2015), “Business Tax Reformed to VAT’ impact on investment, $\mathrm{R} \& \mathrm{D}$ and employment of firms - based on DID model”, China Economic Issues, no.4, pp. 3-13.

Liu, X. (2012), Research on the implementation of value-added tax on traffic and transportation industry, Beijing Jiaotong University, Beijing.

Liu, X. K. (2004), Empirical study of skilled cooperation's impact on firms' bargaining pow, Chongqing University, Chongqing.

Qian, C.H. (2013), “Construction industry 'Business Tax Reformed to VAT’ project cost countermeasures and impact analysis”, Construction Economy, no.7, pp. 18-21.

Tang, H.B. (2016), "Business Tax Reformed to" VAT’ impact on construction firms and countermeasures”, Management Manager, no.1, pp. 41.

Tian, Z. W. \& Hu, Y. J. (2014), "Research on the difference of 'Business Tax Reformed to VAT' effect on Shanghai and the whole country”, Journal of Shanghai University of Finance and Economics, no.2, pp. 75-82.

Tian, Z. W. \& Hu, Y. J. (2013), “Dynamic analysis of 'Business Tax Reformed to VAT' effect on tax burden of different industries", Finance and Economics, no.4, pp. 29-34.

Wang, J. J. (2011), Research on the implementation of value-added tax on Construction industry, Northeast University of Finance and Economics, Jilin.

Wang, J. N. (2014), Empirical study on 'Business Tax Reformed to VAT' impact on listed companies in logistics industry, Northeast Petroleum University, Liaoning.

Wang, J.R. (2013), Research on 'Business Tax Reformed to VAT' reform on modern service industry, Shandong University of Finance and Economics, Shandong.

Yang, M. (2014), Empirical study on 'Business Tax Reformed to VAT' impact on financial performance of listed companies, South China University of Technology, Guangzhou.

Zhang, Y. H. (2008), "Foreign value-added tax system comparison and recommendations to our country”. Modern Commerce Industry, no.3, pp. 46-47.

Zhang, X. (2013), "China's export firms bargaining power measurement - based on China's industrial exports of bilateral arbitrary boundary analysis”, Journal of 
Zhongnan University of Economics and Law, no.3, pp. 51-58.

Zheng, D. P. \& Zhang, D. (2016), "Supplier and customer participation in the impact of technological innovation performance - consider the bargaining power of suppliers and customers”, Technology economy, no.6.

Zhao, F. (2012), “The necessity of 'Business Tax Reformed to VAT”, Business Economy, no.6, pp. 94-95. 